\title{
REPRODUCTION AND DISPERSAL IN THE ANT CATAGLYPHIS CURSOR (HYMENOPTERA, FORMICIDAE)
}

\author{
By A. Lenoir ${ }^{1}$, L. Querard ${ }^{2}$, N. PondicQ ${ }^{2}$ AND F. Berton ${ }^{2}$
}

\section{INTRODUCTION}

Cataglyphis cursor (Fonscolombe 1846) is a Mediterranean formicine species, living in dry and arid habitats which have sparce vegetation (Cagniant 1976a). It is also found in areas covered with relatively abundant vegetation, for example in Provence near Apt in abandonned lavender fields (Lenoir et al. in prep.) or in meadows of the Catalan coast near Barcelona (Retana, in prep.). Societies are considered to be monogynous and monodomous (Cagniant 1976b, Retana 1986). Elsewhere Cagniant (1973) and Suzzoni and Cagniant (1975) observed, in the laboratory, that orphan workers of this species are able to reproduce by thelytokous parthenogenesis, which enables the colony to gain a recently inseminated queen. As neither queenless colonies, nor isolated females, have ever been observed in the field, we wished to investigate modes of colony foundation in this species.

\section{MATERIAL AND MethodS}

All observations were made during July and August from 1983 to 1986 in 3 sites in France: near Apt (Vaucluse-500 m high), near Le Muy (Var-150, $200 \mathrm{~m}$ ), and on the edge of the Etang de Leucate (St-Hippolyte, Pyr-Orientales, sea level). In some of the sites the entrances of the nests were flagged with a numbered label. When necessary workers and sexuals were captured. They were marked with a dot of paint "céramique à froid" and released 5 or 10 minutes later. This technique was tested in the laboratory, where marked ants immediately reentered their nest without hostility from their nestmates. Marked individuals did not have a higher mortality rate

'Laboratoire d'Ethologie et Sociobiologie, UA CNRS 667 Université Paris Nord, av. J. B. Clément, F-93430 VILLETANEUSE, FRANCE.

${ }^{2}$ Laboratoire d'Ethologie et Psychophysiologie, Faculté des Sciences, Parc de Grandmont, F-37200 TOURS, FRANCE.

Manuscript received by the editor December 15, 1987. 
(at least over a few weeks). All observations were carried out during the day from 8 to $16 \mathrm{~h}$ (Solar Time), which covered all the period of activity of these strictly diurnal ants (Lenoir et al., in prep.).

\section{RESULTS}

\section{Number of queens per colony}

Excavation of a nest is easy because of its predictable structure. Under the superficial chambers is a vertical well, which covers chambers where a great number of workers are packed with brood and the queen (Cagniant 1976b). Sometimes the well begins after a more or less inclined tunnel. In each case the queen was found (except when digging was impossible-for example when the nest was under a large stone). The queen was located at various depths, generally 40 to $80 \mathrm{~cm}$ deep in April. She moves up in May when the soil is moist, she goes deeper during drier periods. The exact position depends on the nature of the substrate (Cagniant 1976a). In sand, for example on the edge of the Etang de Leucate, nests are above the water level, which is at $60 \mathrm{~cm}$. In limestone they are deeper. More than 150 nests were dug up; each contained only one queen. During a short period following swarming, however, colonies may contain several inseminated females and are temporarily polygynous (see below). In May 1986 one colony was found at St-Hippolyte (Pyr-Or.) with 3 queens. This colony was reared in the laboratory, and we observed the rejection of supernumerary queens on the 5th of July. The two rejected queens were dissected and it appeared that they were not inseminated, so they cannot be considered as true queens.

\section{Colony size}

Fig. 1 represents the number of workers in late April/beginning of May before the first brood appearance. It is known that no brood is present during wintering (Cagniant 1976b, Retana 1986). Estimation of colony size is relatively easy. The nest can be excavated during the resting hours when all the ants are in the nest. With the help of a battery-operated vacuum equipment all the workers and brood can be systematically removed and counted.

The mean number of workers is 675.5 (SD $440, n=24$, range 34-1590). Cagniant (1976b) found the mean number to be 600 (range 5-1300) and Retana (1986) states that worker number varies from 150 to 1500 . C. bicolor colonies have, on average, 2600 


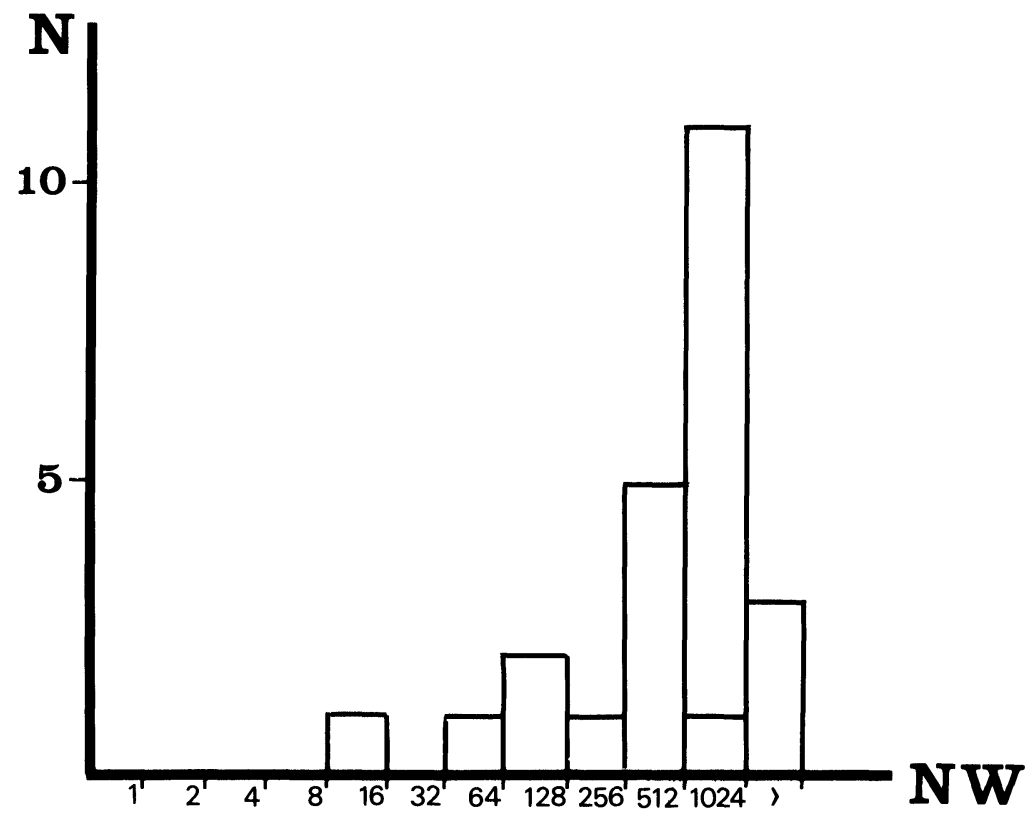

Fig. 1. Frequency of number of workers per colony, including data from Cagniant 1980 (34 workers), and from Cagniant 1983 (1106 workers) N: Number of colonies NW: Number of Workers.

workers; C. albicans has 700 (Schmid-Hempel 1987). Figure 1 shows that small colonies are not frequent. Isolated females were not found at any time of the year. Cagniant (1980) found only one small colony with 34 workers, but never isolated queens. In ant species which form new colonies with a solitary female (haplometrosis) it is common to find an isolated queen, or a queen surrounded by a few workers (Wilson 1971). This fact suggests that haplometrosis is unusual or absent in C. cursor.

\section{Behavior of sexuals and mating}

The mating period occurs from mid-June until the end of July, depending on the year and the climate. In the Pyrénées-Orientales flight season is finished at the end of June; in the Luberon (Vaucluse) at $500 \mathrm{~m}$ it ends one month later. These data are in agreement with the observations of Bernard (1968) and Cagniant (1976b). In Barcelona sexuals appear at the end of May and leave the nest in June (Retana 1986). The exit of sexuals occurs between $9 \mathrm{~h}$ and $14 \mathrm{~h}$ 
(ST), which are the warmest hours of the day. Frequently males and females from one nest do not come out simultaneously (also in $C$. sabulosa (Shalmon 1981) and C. bicolor (Schmid-Hempel 1987)).

Behavior of males before mating

Fonscolombe (1846) observed males running around nest entrances. Such behavior can be observed frequently in early summer in the Mediterranean region. When they reach the exit of the nest, the males stop for a few seconds and then fly off. Males are apparently able to fly distances greater than several tens of meters, but we were unable to estimate their exact range. Apparently they do not often come back to their native nest; males captured and marked at the exit of one nest were never seen returning same place $(n=16)$. When a male arrives within $10-15 \mathrm{~cm}$ from a nest entrance, he may stay there motionless for several minutes; he may be attacked by workers. When marked males are recaptured later, recapture occurs near the nest entrance where they were originally captured $(12 \%$ were seen again; $n=25$ ).

This observation contradicts the suggestions of Cagniant (1976b), who supposed that mating occurs between the members of the same colony. Apparently this must be exceptional: outbreeding appears to be the rule. In the laboratory we did not observe spontaneous matings between siblings whereas it is easy to produce matings by introducing alien males (observed previously by Cagniant, pers. comm.).

Behavior of females before mating

Alate females often come timidly to the exit of the nest before they finally leave. When alate females prepare to leave the nest, workers and males frequently dance around the entrance. Workers are very aggressive towards males and may kill them: this could indicate that they are from a different colony. Females walk around the nest, within a radius of $1 \mathrm{~m}$. Apparently they cannot fly. Are the wings too short, as supposed by Cagniant (1976b)? Wings seem to be normal but it must be measured in comparison with other species. Santschi (1929) observed one apterous species: $C$. theryi. If males are present, mating occurs immediately. If several males are present around a female, some slight aggressive behaviour may be noticed between the males. In the absence of males, females climb onto a stone or a twig for a few minutes and then descend. They then begin a "sexual calling" behavior, with the gaster bent under 
the thorax several times during 2 or $3 \mathrm{~min}$. If no male arrives, they reenter their nest, but frequently males do appear and mate. This female-climbing behavior may be interpreted in two ways. First, a sexual attractant pheromone might be emitted as suggested by the position of the abdomen. Sexual pheromones are known in some ant species (see Discussion). The fact that females do not fly renders use of sexual pheromones an advantage for this species. A second explanation is that the female is more easily seen by the males. It is known that Cataglyphis ants have a well developed visual system and workers orientate by vision during their foraging trips (Wehner et al. 1983). Males may also use vision to locate females. Acoustic communication by wing vibration is improbable because it cannot be used for distanct communication, and has not yet been observed in the sexual behavior of ants.

\section{Mating}

In C. cursor mating occurs on the ground (Cagniant 1976b) near the females nest during the hottest hours of the day ( 9 to $14 \mathrm{~h}$ ). It lasts from some seconds to one minute. Two positions are possible: the male behind and above the female facing in the same direction, or the male facing in the opposite direction touching the female only by the extremity of the gaster. One male can copulate successively with several females after no more than a one minute intermission. Females may mate successively with one male or with different males. On various occasions in which males and females were present, mating did not occur for unknown reasons.

Male behavior after mating

Following copulation, males stay around the nest. During the night they crawl under stones or on twigs, with their heads directed toward the soil. They die rapidly: life span is probably not longer than 2 or 3 days. They are aggressed by $C$. cursor workers, or killed by predators, essentially spiders. Bernard noted the existence of nocturnal aggregation of C. cursor males (in Grassé 1942).

Female behavior after mating

After mating, newly inseminated alate females reenter the nest but sometimes run frenetically around the nest for several minutes. They are helped to reenter the nest by workers. Perhaps the females have difficulty in orienting themselves because it is their first foray into the open. When inseminated, females stay in the nest. These females will soon lose their wings in the nest. During the following days 
apterous females may come out and mate again. They are generally inseminated but dissections have shown that there are exceptions. It is well known in ants that virgin queens lose their wings after some delay if they are not inseminated. During this period we find polygynous nests in the field. Such nests are rare and polygyny lasts only a few days. Supernumerary queens are rejected by workers if budding does not occur rapidly. Ostracized queens leave the nest and die. We dissected 2 of these rejected queens: they were not inseminated. Dead queens are also expelled from the nest.

Mating in the laboratory

We obtained matings between sexuals of different colonies in the laboratory. The length of mating was variable, from $40 \mathrm{sec}$. to more than 16 minutes $($ mean $=333 \mathrm{~s} ; \mathrm{n}=9)$. This may have been related to the low temperature of the laboratory $\left(25^{\circ} \mathrm{C}\right)$. These observations are comparable to others in Formica where the mean time is $3.1 \mathrm{~min}$ (range 0.5-7.5 min) (Rosengren et al. 1986). The presence of a full spermatheca indicated a successful copulation. In all the observed cases the females reentered their artificial nest. During this period the societies are polygynous with the old queen and newly inseminated queens. In the laboratory some colonies kept several queens for a long time (until wintering). Later they again became monogynous. The mechanism for the elimination of supernumerary queens is unknown: aggression between queens or aggression of queens by workers? Is the surviving queen the old queen? In our colonies the surviving queen was not the old one (as indicated by individual marking), but additional observations are needed.

\section{Foundation of new colonies}

Budding was observed twice in the field in 1985, after the period of mating. Workers transported larvae, cocoons and other workers to a new nest. We may suppose that explorers had previously localized unoccupied holes which could be used as a new nest site. Transporting workers made many journeys between the two nests. Moving was directed towards 3 nest sites in the 1st case (Fig. 2) and 4 nest sites in the second case. The mean distance to the new nests was $6.5 \mathrm{~m}$ (range $3.2-11.3 \mathrm{~m}$ ).

Traffic lasted for two days. In Fig. 2 shows that nest 2 was abandoned, and then occupied later by a colony which moved totally from nest 1 . Nest 5 was abandoned after 3 weeks and the colony divided in two sister colonies, at least one of which had a new queen. 


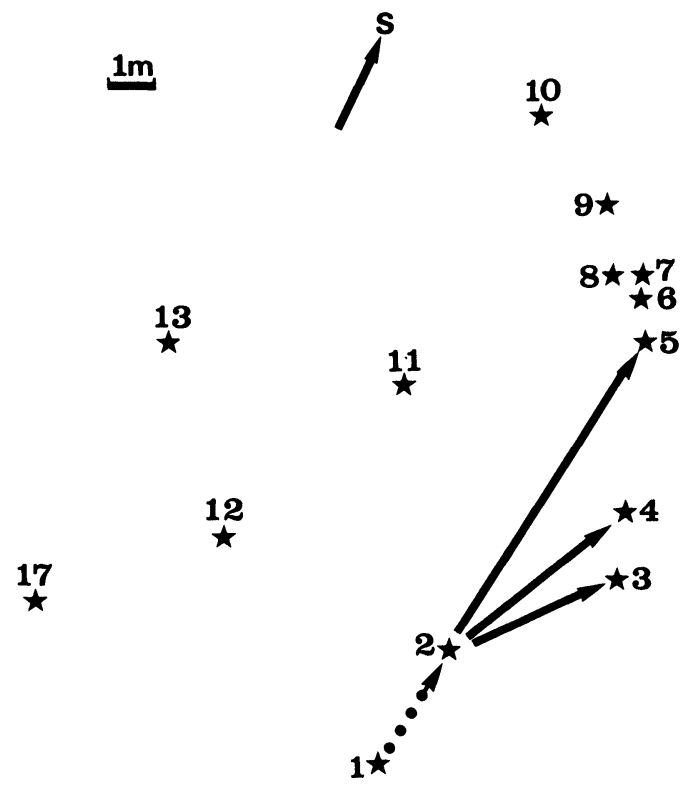

21

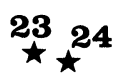

$\underset{\star}{22}$

$\underset{\star}{25}$

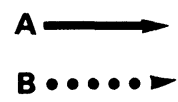

Fig. 2. Map of a population of $C$. cursor colonies showing a budding process. Asterisks indicate positions of the nests. A: fission of colony 2 into 3 daughter colonies 3,4 , and 5. B: second step = nest-moving of colony 1 to the abandoned nest site 2 .

In the second observed budding the colony emigratd completely and divided into 4 nests, 2 of which were later abandoned. The two remaining sister nests were dug later, and they comprised 141 and 195 workers each with a new inseminated queen (recognized by a dot of paint). The two colonies were of small size, perhaps because 
the mother colony was located at $0.8 \mathrm{~m}$ from a big colony with more than 1000 workers. Traffic between the mother and daughter nests was measured for periods of $5 \mathrm{mn}$ during the maximum activity period of the budding day. 6 to 9 workers were transported during 5 $\mathrm{mn}$, which could indicate a population in daughter nests of at least 250-300 workers. Probably some transported workers returned to their mother nest. Division of labor for moving has not been studied: it is not known if the transporters are specialized ants. After budding the new colonies were not very active. It is not known if the old queen survives. In the 4 cases where it was possible to examine this with marked queens the surviving queen was a newly inseminated queen, but we cannot make any decisive conclusion with so few observations.

Colony foundation with isolated queens

A few experiments were conducted with newly inseminated queens either isolated $(n=5)$ or with 4 or 5 workers $(n=4)$. Isolated females die in a few weeks and rarely lay eggs (also observed by Cagniant, pers. comm.) Females associated with workers can live for several months, and sometimes longer after wintering. Some larvae were observed but they never developed into callow workers (also Cagniant pers. comm.). These data need to be confirmed with larger samples but it seems that isolated foundation does not exist in C. cursor. If possible, it is surely an accessory mode of reproduction of colonies.

A new argument against isolated foundation can be found in the weight of queens and workers. It is generally considered that species with haplometrotic foundation have larger queens relative to the size of their workers (Wheeler 1910, Sudd 1967, Wilson 1971). Most monogynous species have large queens that are highly differentiated from the workers (Baroni Urbani 1968). Table 1 shows that foundresses of Lasius niger are 44 times heavier than their nanitic workers. In Liometopum occidentale and L. apiculatum, two Mexican Dolichoderinae species founding in isolation, the proportions are respectively 33 and 45 . In contrast, in mature colonies of $L$. niger the queen/worker ratio is less than 10: workers of mature colonies are 4 times heavier than nanitic workers of young colonies. In Solenopsis invicta the first nanitic workers weigh $0.33 \mathrm{mg}$, the second generation workers $0.6 \mathrm{mg}$ and the workers of mature colonies 0.5 to $1.92 \mathrm{mg}$ (Porter and Tshinkel 1986). By comparison, in small 
colonies of $C$. cursor the female is only 1.8 to 3 times the weight of workers. We never found colonies with nanitic workers. We weighed the workers in a small colony composed of 31 workers: they were on average heavier than the overall mean. Perhaps the largest workers, more resistant, are more likely to survive in small colonies issued from budding. This needs to be confirmed with additional small colonies.

The situation is not so simple as in Iridomyrmex humilis, a species forming a unique giant polydomous nest in the south of France, where young societies do not exist. The ratio $\mathrm{Q} / \mathrm{W}$ is 8.28 (Passera and Keller, in prep.). We conclude that a ratio of $30-40$ is proof of an independent foundation but a ratio of 7-10 is inconclusive.

\section{Internest Relations}

We observed workers leaving a nest and then entering into a neighboring nest. The workers of these nests were marked with one color for each nest, so that traffic at the entrance could be measured. The data presented here were collected on the plateau of Claparède near Apt (Vaucluse) during July 1983 between 2 nests one meter apart (nest 1 and nest 0 ). Direct journeys between the two nests were recorded. In most of the passages the workers were not loaded, although they sometimes transported cocoons, a worker or prey. The transporting workers of colony 1 reinforce their society as their traffic is important in direction of colony 0 (Table 2).

The data in Table 2 are indicative because only $50 \%$ of the observed ants were marked. This means that the real flux of exchanges was probably double. Table 2 shows that colony 1 is more active at the entrance of colony 0 . The activity also varies greatly according to days.

These two colonies were excavated at the end of August: in colony 1 we found 750 workers and 1500 in colony 0 . In this case it seems that traffic is inversely proportional with the size of the colony. From the 1st to the 5th of August a second set of observations permitted us to quantify the proportion of ants of one nest found at the entrance of another nest. Each alien ant observed at one entrance was marked with a second spot of paint indicating the number of this entrance. In this experimental design each worker is counted only once. 2 new nests appeared during this period: nest 10 at $40 \mathrm{~cm}$ from nest 0 and nest 11 at $1.6 \mathrm{~m}$ from nest 1 . 


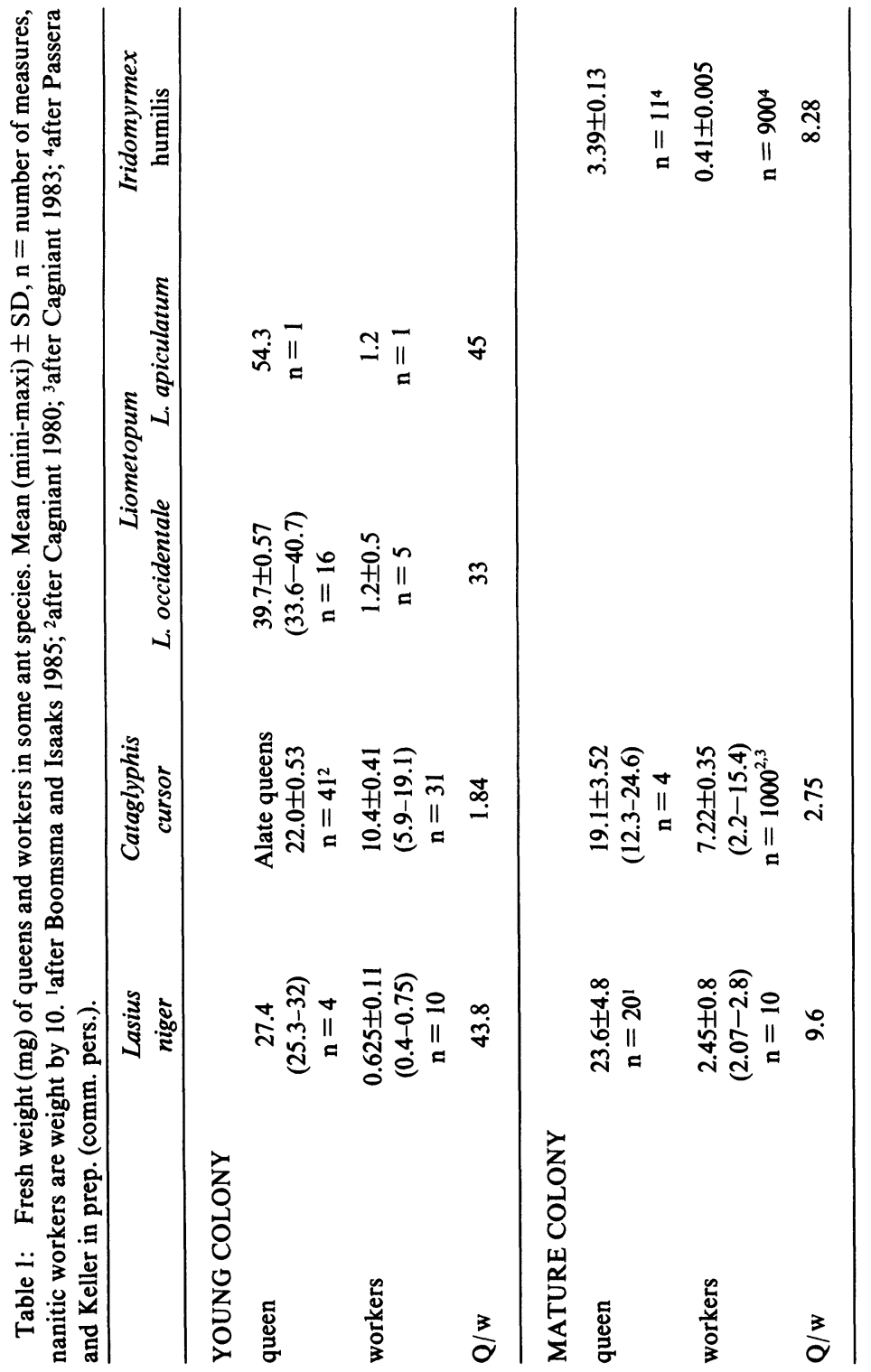


Table 2. Number of alien workers leaving or entering nests 0 or 1 (duration of observations $1 \mathrm{~h}$ by periods of $5 \mathrm{mn}$ during the day).

\begin{tabular}{lcc}
\hline Date & $\begin{array}{c}\text { Ants from nest } 1 \text { at } \\
\text { entrance of nest } 0\end{array}$ & $\begin{array}{c}\text { Ants from nest } 0 \text { at } \\
\text { entrance of nest } 1\end{array}$ \\
\hline $22 / 7 / 83$ & 136 & 36 \\
23 & 33 & 3 \\
25 & 17 & 65 \\
26 & 34 & 44 \\
27 & 55 & 38 \\
28 & 21 & 12 \\
29 & 84 & 12 \\
mean & 54.3 & 30 \\
\hline nb workers of colony 1: 750 & colony 0: 1500 & \\
\hline
\end{tabular}

The two new nests were much less active and nest 11 was closed before the end of the five days observation. Nest 10 closed a few days later and was in fact a secondary nest for colony 0 (when we dug we found superficial galleries connecting 0 and 10). Nevertheless, it was surprising to observe above-ground cocoon transport between the two nests. Nests 10 and 11 were abandoned after their closing. Some exchanges were also observed between more distant nests (4.4 m apart). In another case cocoon transport was observed between two colonies $60 \mathrm{~cm}$ apart (each colony had its own queen). Some transport of prey was also observed here, which could be interpreted as intercolonial robbing. This phenomenon seems to be frequent in some ponerine species, e.g. Ectatomma tuberculatum (Lachaud pers. comm.).

These observations can be explained by the mode of foundation of new colonies: it is probable that colonies 1 and 0 are sister colonies, given that they keep strong links. The workers probably have a similar colony odor and do not attack each other, which may permit robbing of cocoons or prey. It is more difficult to interpret the late budding trials for nests 10 and 11 . When workers occupy a new nest for several days, they transport cocoons. If there is no queen available, they abandon the provisional nest ( 84 workers were marked at the entrance to nest 11; when it was excavated we found only 4 workers). This reflects a tendency toward budding to form new societies after the mating season. Other budding trials were observed: one with 4 workers and 5 cocoons, another with 30 workers and a few cocoons, another completely abandoned. 
Table 3. \% of workers of one nest observed at the entrance of another nest.

\begin{tabular}{lcccccc}
\hline & \multicolumn{5}{c}{ Destination nest } & \multicolumn{1}{c}{ Number of } \\
& & 0 & 1 & 10 & 11 & workers \\
\hline \multirow{3}{*}{ Source } & 0 & $75.4 \%$ & $10.6 \%$ & $14 \%$ & $0 \%$ & 236 \\
nest & 1 & 5 & 93.2 & 1.8 & 0 & 163 \\
& 10 & 22.6 & 11.8 & 65.6 & 0 & 93 \\
& 11 & 7.1 & 38.1 & 3.6 & 51.2 & 84 \\
\hline
\end{tabular}

Additional field experiments confirmed the existence of relatedness between interacting societies. In July 1984, 3 colonies were orphaned and all the workers marked with a dot of paint. They were abandoned the next day either at their old nest, or at a distance of two hundred meters. In the former case we observed numerous transports of workers and brood in direction of neighboring nests, whereas in the latter case no transport occurred (Lenoir and Cagniant 1986). Transports are probably possible if the abandoned workers are closely related to the resident ants. When the colonies are near, they are probably related by budding. We tested this hypothesis at St-Hippolyte (Pyr. Or.) during 1986. When a colony is excavated to remove the queen, although workers are not marked, it is easy to observe transports in direction of neighboring colonies. This phenomenon is possible because immature workers found by foragers in the outside arena are retrieved into the nest. (Nowbahari and Lenoir, MS). Bonavita and Clément (1986) observed the same behavior with Camponotus vagus nurses where foragers retrieve all ants (callows, nurses) into the nest which are not normally there.

To experiment on the closure of societies, workers were transferred to the entrance of another society. A worker was captured when leaving its nest, marked and placed near the entrance (less than $5 \mathrm{~cm}$ ) of an alien nest in a small box. When the ant was calm the box was opened and the behavior of the ant noted for $5 \mathrm{~min}$. Five recipient nests were chosen, the intruders coming from various nests more or less distant $(\max .50 \mathrm{~m})$. The results are presented in Table 4.

$84 \%$ of control workers enter their own nest within the $5 \mathrm{~min}$ observation, while only $22.5 \%$ of displaced workers entered the foreign nest. It is not known if these ants were adopted or were later rejected. 4 of them were observed during the following days: they 
Table 4. Transfer experiments, $\%$ of workers entering the nest, $n=$ number of ants tested, $x^{2}=92.868(P<.001), x^{2}$ for experimental group $=6.595(\mathrm{NS})$.

\begin{tabular}{lcccccc}
\hline & controls & 1 & 2 & 3 & 4 & 5 \\
\hline $\begin{array}{l}\text { \% workers } \\
\text { entering } \\
\text { the nest }\end{array}$ & 84 & 7.5 & 25 & 27.5 & 27.5 & 25 \\
\hline $\mathrm{n}$ & 50 & 40 & 40 & 40 & 40 & 40 \\
\hline
\end{tabular}

behaved normally in their new colony where they seemed to be completely adopted. Some nests are very closed: only $7.5 \%$ of ants entered nest 1 . Control ants, after marking, seemed to recognize their entrance and they were ignored by resident ants: in 50 tests they encountered only 9 resident ants $(18 \%)$. On the contrary alien ants were more excited and they more frequently encountered the resident ants (35.5\%). Encounters were followed by aggressive reaction in 2 cases for controls and in 34 out of 71 (47.9\%) cases for aliens, which were sometimes dragged as prey (Table 5).

These experiments show that most colonies are relatively open: they tolerate and adopt foragers of neighboring societies. We did not find a correlation between the $\%$ of adoption and distance between the nests, except for very close nests $(1 \mathrm{~m}$ or less) which accept 90 or $100 \%$ of aliens. For greater distances (but still less than $50 \mathrm{~m}$ ) the \% of adoption varies from 0 to $90 \%$ regardless of the distance. These results indicate that colonies in the same habitat behave more or less as kin. It is a supplementary argument in favor of the budding process for dissemination unless the results indicate nothing about the actual relationship between colonies.

\section{Role of parthenogenesis in colony foundation}

Cagniant (1973) observed in the laboratory that C. cursor workers can reproduce by thelytokous parthenogenesis. This phenomenon was later studied in detail by Suzzoni and Cagniant (1975) and Cagniant (1980, 1982, 1983, 1984).

When orphaned in the laboratory after wintering, non-inseminated workers lay diploid eggs which produce workers and females. The sexuals leave the nest, females are inseminated by flying males and reenter the nest. In this way the colony can get a new queen. This sequence was easily verified in our laboratory. The existence of parthenogenesis in the field is, however very doubtful. Lenoir and 
Table 5. Behavior of transferred ants and reaction toward resident ants.

\begin{tabular}{lcc}
\hline & Control & Alien \\
\hline Resident reaction & 1 & \\
Attacked & 0 & 1 \\
Escape & 1 & 15 \\
Dragged as prey & 0 & 16 \\
Submission & 9 & 2 \\
Number of encounters & $2 / 9$ & 71 \\
Aggressive & $(22 \%)$ & $34 / 71$ \\
encounters & $18 \%$ & $(47.9 \%)$ \\
\% of tested ants & 50 & $35.5 \%$ \\
\hline Number of ants tested & & 200 \\
\hline
\end{tabular}

Cagniant (1986) hypothesized that groups of workers which leave the nest at the end of the summer (as indicated in paragraph 5) could produce sexuals during the next springtime by parthenogenesis. If this occurred we should from time to time find groups of orphan workers, but that was never the case. Moreover it was observed that during budding, groups of workers transport a young queen, who is preventing parthenogenesis. Thus, if parthenogenesis occurs under natural conditions, it seems to be an accessory mechanism (for example in the case of queen death). These ants live frequently in sandy sites where nest collapse may occur. Thelytoky may also occur when the queen is senescent and becomes sterile. To verify this, we orphaned several colonies in late April or during the first days of May before the queens had laid eggs. 22 colonies were dug up and the queen removed together with a hundred workers which were reared in the laboratory. The rest of the colony was left on the site. Seven of these orphaned colonies were found in July exactly at the same place with an inseminated functional queen laying small eggs, which are characteristic of queen eggs (Cagniant 1982). Six of these colonies were easily distinguished from other normal neighboring colonies: they had a small number of workers $(102.5, n=4$ vs $577.5, n=4)$ and very few cocoons (cocoons are numerous in normal colonies). In these orphaned colonies, the ratio of cocoons: workers was less than $10 \%$, versus $43 \%$ in normal colonies. Two colonies did not yet have cocoons. The seventh colony had a large number of cocoons and is probably another colony which had moved. The small size of orphaned colonies is the consequence of the perturbation induced by artificial orphaning. 
In the laboratory, recognition tests were performed with the sister groups of workers: old workers reared in the laboratory after orphaning and the new ones captured in the field in July. It is known that $C$. cursor societies recognize their sisters and readopt them more easily then strangers $(80 \%$ vs $50 \%$-Berton and Lenoir 1986). Recognition tests were performed for colonies number 1 to 4 : 75 to $85 \%$ of adoptions were observed which is in agreement with the fact that the workers were siblings. In colony number 7 only $40 \%$ of ants were adopted, suggesting that it was another colony. A doubt persists about the origin of the queen: was she produced by parthenogenesis or was she adopted after swarming from normal colonies? The second hypothesis seems to be improbable as it has been shown that closure is fairly similar in orphan and normal societies (Berton and Lenoir 1986), so adoption of a new queen must be difficult. This needs to be verified in the field by observations during the swarming period.

\section{Discussion}

We have confirmed that Cataglyphis cursor is a monogynous and monodomous species as indicated by Cagniant (1976b) and contrary to Bernard who thought that females were rare (1968) or absent (1983). It seems that all the species of the genus are monogynous but some can be polydomous. C. iberica (De Haro and Cerda 1984), $C$. bicolor (Wehner et al. 1983), C. albicans (Cerda 1986, SchmidHempel 1987) and the five species from Israel (Shalmon 1982) have polycalic societies with a principal nest containing the queen and secondary queenless nests. In these societies workers are observed passing from one nest to another transporting workers and brood. C. hispanica could be monodomous as we collected two queenright societies near Toleda (Spain), but this needs to be confirmed.

Dispersal of the species

This does not seem to be carried out by solitary females as is frequently the case in monogynous ants. Numerous arguments have been presented here that lead us to reject this possibility for $C$. cursor in favor of a budding process. The nuptial flight is replaced by a nuptial race and the inseminated females reenter their natal nest. During a few days polygynous societies can be found. Later, a group of workers leaves the mother nest with brood, other workers and a young queen. De Haro (1981) observed one queen transport 
between two nests of $C$. cursor: this could have been during a budding period. After budding the sister colonies keep contact and numerous exchanges are possible. Sometimes the smaller colony continues to reinforce itself. As a consequence of this form of dispersal, colonies in the same habitat are probably kin. This explains the fact that some displaced workers can be adopted into an alien colony, and that nurses and callows found on the surface are transported by foragers into the nest (cf par. 5). This result has also to be related to the adoption experiments conducted in the laboratory by Nowbahari and Lenoir (1984): 50\% of the workers introduced into an alien colony are adopted if they originate from the same habitat. This is surprising for monogynous species which are generally considered to have closed societies (Hölldobler and Wilson 1977).

Readoption of newly inseminated females is not exceptional in polygynous species, for example in mound-building Formica, Iridomyrmex humilis, Monomorium pharaonis, Myrmica ruginodis microgyna, Lasius sakagamii (see Hölldobler and Wilson 1977, Rosengren and Pamilo 1983, Yamauchi et al. 1981). Budding is usual in polygynous social insects like termites as discovered by Grassé and Noirot (1951) in Anophotermes and Trinervitermes. These authors called the phenomenon Sociotomy: a fragmentation of the society in different parts where the castes are represented and which can reproduce a complete society (Grassé 1984). New data are available on Nasutitermes (Thorne 1982, 1984; Roisin and Pasteels $1986 \mathrm{a}, \mathrm{b})$. Budding is exceptional in wasps where it is known only for Polybinii (Evans and West-Eberhard 1970, Spradberry 1973). Budding seems also to exist in social spiders (Agelena consociata, Darchen 1978; Achaeranea wau, Lubin and Robinson 1982). In ants it is found in polygynous and polydomous species like Lasius sakagamii (Yamauchi et al. 1981), the Formica rufa group (F. aquilonia and F. polyctena (Mabelis 1979, Rosengren and Pamilo 1983) and in Leptothorax curvispinosus (Stuart 1985). It occurs also in Ponerinae lacking a reproductive caste like some Rhytidoponera species, or Ophtalmopone berthoudi, where workers are inseminated (Crozier et al. 1984, Peeters and Crewe 1984, Pamilo et al. 1985). Traniello (1982) pointed out that budding could exist in Amblyopone pallipes but precise observations are missing. Budding is the rule in Dorylinae army ants: the colony reproduces by binary fission, one group containing the old queen and the other the successful daughter queen (Schneirla and Brown 1950, Raignier and van Boven 1955, 
Rettenmeyer 1963, Franks 1985). This mechanism is similar to the swarming of bees. Budding was noted in Oecophylla by Ledoux (1950) who thought that groups of workers could be isolated from the colony and reproduce a new queen by thelytokous parthenogenesis, but it was not confirmed by Hölldobler and Wilson (1983). Ledoux $(1971,1973,1976)$ also observed budding in Aphaenogaster senilis where the majority of workers leave the nest with the abandoned brood of the old queen. This mechanism, if confirmed, is different from the one observed in C. cursor where budding occurs by splitting the society in different groups, each having its own queen. Iridomyrmex purpureus has a remarkable diversity in its mode of colony foundation. New colonies can originate from a single foundress (haplometrosis), or foundress associations, or by colony budding, or by adoption of newly-mated queens (Hölldobler and Carlin 1986). Claustral colony foundation and colony fission were also observed in Chelaner sp. a probably polygynous ant from Australia (Briese 1983). Colony fission seems to appear in this species under stress conditions such as drought. Colombel (1972) observed in Odontomachus troglodytes $(=O$. haematodes) a grafting process where a new isolated queen can attract workers from surrounding colonies. This could explain similar observations on $O$. assiniensis (Ledoux 1952). It seems, after this review, that Cataglyphis cursor is the first observed occurrence of a real budding process in monogynous, monodomous non-nomadic ants. Very little is known about the foundation of other Cataglyphis species. Cerda (1986) demonstrated that the polycalic $C$. iberica can produce new nests by fission, but the mode of foundation of new societies is unknown. Fridman and Avital (1983) observed foundresses of $C$. bicolor nigra bringing dead ants back to their nesting hole. This unique observation, which needs to be confirmed, could indicate an independent foundation, and that Cataglyphis is an heterogeneous genus. However, Schmid-Hempel never observed this phenomenon in C. bicolor during a two years study in Tunisia (Comm. pers).

\section{Mating Behaviour}

Hölldobler and Bartz (1985) distinguished two types of strategies in mating behaviour. The first is called the "male aggregation syndrome." It is characteristic of species that form very large colonies. Males gather at specific mating sites where females fly to mate. Males produce a sexual attractant pheromone as in Camponotus 
(Hölldobler and Maschwitz 1965). Multiple insemination is common among these species. The second strategy, called "female calling syndrome," has been found in several phylogenetically primitive species, and a number of socially parasitic or dulotic ants where the females emit a sexual pheromone attractant. The females usually mate once. Mature colonies of these species tend to be relatively small and produce few new reproductives per year. The mating behaviour of $C$. cursor is probably related to the female callingstrategy, although it is not yet known if the female emits sexual pheromone. The "degeneration" of nuptial flight is known in other species: in Formica uralensis where females reenter their nest after insemination which occurs frequently with brothers (Rosengren and Pamilo 1983) and in parasitic species where mating occurs in or near the host nest (Wilson 1971). In Cataglyphis the absence of nuptial flight is the rule but at least in one species (C. sabulosa) females fly some distance (Shalmon 1981).

\section{Parthenogenesis}

As indicated thelytokous parthenogenesis seems to be an accessory mechanism in the reproduction of the societies of $C$. cursor. We do not have much information about parthenogenesis in other Cataglyphis species: Cerda (1986) failed to find it in C. iberica, but recent experiments indicate that it exists in $C$. bicolor (Dartigues et al. in prep). In bees Apis mellifera capensis orphan workers are also able to reproduce by thelytoky but they become very aggressive and mortality is important (Anderson 1963, Moritz 1986). In ants the only certain case is Pristomyrmex pungens, a myrmicine lacking a queen (Mizutani 1980, Ono 1983, Itow et al. 1984). Other reports in the literature need to be confirmed. Ledoux (1950) supposed that parthenogenesis could play a central role in the life cycle of the weaver ant Oecophylla longinoda where alternation of generation methods may appear: foundation by inseminated queens, and fission by groups of workers which rear new queens by thelytoky. Unfortunately this result was not observed by Way (1954) or by Hölldobler and Wilson (1983). A similar cycle has been proposed for Harpagoxenus americanus (Wesson 1939), and four species of Crematogaster (Soulié 1960). For the first species Buschinger and Winter (1978) demonstrated that the production of diploid eggs was due to ergatoid inseminated females. Lasius niger (various authors and Bier 1952), Lasius flavus (Leutert 1963), Atta cephalotes (in 
Wilson 1971), Formica polyctena (Otto 1960) are reported as thelytokous species but the data are not very convincing. Often they are not confirmed (as in Atta, Bazire-Benazet 1970). In Aphaenogaster senilis thelytoky seems to exceptionally appear after a thermic shock to workers (Ledoux 1984). Thelytoky has also been noted in virgin females of two species of Aphaenogaster (Haskins and Enzmann 1945), Solenopsis invicta (Tshinkel and Howard 1978), and perhaps in the termite Reticulitermes (Howard et al. 1981).

In summary Cataglyphis cursor is a remarkable Formicine species: females do not fly and instead mate near their natal nest which they re-enter. Societies reproduce by budding with the departure of workers with a young queen. Dispersal distance is limited to the walking range of workers (less than ten meters). Neighboring societies are more or less closely related and this permits a particular strategy for exploiting the resources of their habitat (Lenoir $e t$ al. in prep.). This species may reproduce by thelytoky but it seems to be an accessory possibility in the case of the queen death.

\section{ACKNOWLEDGMENTS}

Financial support was provided by CNRS (Population Biology Program). We thank J. Ramos for providing Liometopum foundations, B. Corbara, D. Cherix, J. P. Lachaud, J. Retana and P. Schmid-Hempel for critical reading the manuscript. Special thanks are due to L. Passera and H. Cagniant for personal communications and to B. Thorne for improving the English. All the comments were appreciated even if their advice was not always followed.

\section{REFERENCES}

Anderson, R. H. 1963. The laying workers in the Cape honeybee Apis mellifera capensis (Hymenoptera Apidae). J. Apic. Res., 2: 85-92.

Baroni, Urbani C. 1968. Monogyny in ant societies. Zool. Anz., 181: 269-277.

Bazire-Benazet, M. 1970. La ponte des ouvrières d'Atta laevigata Fred Smith 1950. C. R. Acad. Sc. Paris, D, 270: 1614-1615.

BERnARD, F. 1968. Les fourmis d'Europe occidentale et septentrionale. Masson, Paris.

BERnARD, F. 1983. Les fourmis et leur milieu en France méditerranéenne. Lechevalier, Paris.

Berton, F., Lenoir, A. 1986. Fermeture des scoiétés parthénogénétiques de Cataglyphis cursor (Hymenoptera, Formicidae). Actes Coll. Insectes Soc., 3: 197-209. 
BIER, K. 1952. Über den Enfluss der Königin auf die Arbeiterinnenfertilität im Ameisenstaat. Insectes Soc., 1: 7-19.

Bonavita-Cougourdan, A., Clement, J. L. 1986. Processus de reconnaissance chez la fourmi Camponotus vagus scop. Bulletin SFECA, 1: 49-55.

BoomSMA, J. J., IsAAKs, J. A. 1985. Energy investment and respiration in queens and males of Lasius niger (Hymenoptera Formicidae). Behav. Ecol. Sociobiol., 18: 19-27.

BRIESE, D. T. 1983. Different modes of reproductive behaviour (including a description of colony fission) in a species of Chelaner (Hymenopteras Formicidae). Insectes Soc., 30: 308-316.

BUSCHINGER, A., WINTER, U. 1978. Echte arbeiterinnen, fertile arbeiterinen und sterile wirtsweibschen in völkern der dulotischen ameise (Harpagoxenus sublaevis (Nyl.) (Hymenoptera Formicidae). Insectes Soc., 25: 63-78.

Cagniant, H. 1973. Apparition d'ouvrières à partir d'oeufs pondus par des ouvrières chex la fourmi Cataglyphis cursor Fonsc. C. R. Acad. Sc. Paris, 277: 2197-2198.

Cagniant, H. 1976a. Distribution, ecologie et nid de la fourmi Cataglyphis cursor Fonsc. (Hyménoptères Formicidae). Vie et Milieu, 26: sér. C: 265-276.

Cagniant, H. 1976b. Cycle biologique de la fourmi Cataglyphis cursor Fonsc. (Hyménoptères Formicidae). Vie et milieu, 26: sér. C, 277-281.

CAGNIANT, H. 1980. La parthénogenèse thélytoque et arrhénotoque des ouvrières de la fourmi Cataglyphis cursor Fonsc. Etude en élevage de la productivité de sociétés avec reines et de sociétés sans reine. Insectes Soc., 27: 157-174.

Cagniant, H. 1982. La parthénogenèse thélytoque et arrhénotoque chez la fourmi Cataglyphis cursor Fonsc. (Hyménoptères Formicidae). Etude des oeufs pondus par les reines et les ouvrières: morphologie, devenir, influence sur le déterminisme de la caste reine. Insectes Soc. 29: 175-188.

Cagniant, H. 1983. La parthénogenèse thélytoque et arrhénotoque des ouvrières de la fourmi Cataglyphis cursor Fonsc. (Hyménoptères Formicidae). Etude biométrique des ouvrières et de leurs potentialités reproductrices. Insectes Soc., 30: $241-254$.

CAGniant, H. 1984. Influence de la reine sur l'apparition des sexués ailés et sur la ponte des ouvrières chez la fourmi Cataglyphis cursor (Fonscolombe) (Hymenoptères Formicidae). Bull. Soc. Hist. Nat. Toulouse, 120: 99-102.

Cerda, X. 1986. Contribicion al estudio de la etologia y la ecologia de Cataglyphis iberica (Emery 1906). Memoria Licenciatura Ciencias, Univ. Barcelona.

Colombel, P. 1972. Etude de l'évolution et de la fécondation par greffe des colonies d'Odontomachus haematodes L. (Hyménotères Formicidae Ponerinae). Biologia Gabonica, 8: 369-381.

Crozier, R. H. 1970. Caryotypes of twenty-one ant species with reviews of the known ant caryotypes. Canad. J. Genet. Cytol., 12: 109-128.

Crozier, R. H., Pamilo, P., Crozier, Y. C. $1984 . \quad$ Relatedness and microgeographic genetic variation in Rhytidoponera mayri, an australian arid-zone ant. Behav. Ecol. Sociobiol., 15: 143-150.

Darchen, R. 1978. Les essaimages lointains de l'araignée sociale Agelena consociata dans la forêt gabonaise. C. R. Acad. Sc. Paris, 287: 1035-1037. 
De Haro, A. 1981. Valeur adaptative de la monogynie chez les sociétés de Cataglyphis iberica Emery 1906 (Hym. Formicidae). Bull. int. sect. Fr. IUSSI, Toulouse 1981: 80-82.

De Haro, A., Cerda, X. 1984. Communication entre nids à travers le transport d'ouvrières chez Cataglyphis iberica Emery 1906 (Hym. Formicidae). In "Processus d'acquisition précoce. Les communications," A. de Haro and X. Espadaler eds., Public. Univ. Autonoma Barcelone et Soc. Fr. Et. Comp. Anim., 227-233.

Evans, H. E., West Eberhard, M. J. 1970. The wasps, Univ. Michigan Press, Ann Arbor.

Fonscolombe (DE), M. 1846. Notes sur huit espèces nouvelles d'Hyménoptères et de Névroptères, trouvées aux environs d'Aix. Ann. Soc. Ent. Fr., 4: 39-51.

Franks, N. R. 1985. Reproduction, foraging efficiency and workers polymorphism in army ants. In "Experimental Behavioral Ecology and Sociobiology", B. Hölldobler and M. Lindauer eds., Verlag, 91-107.

Fridman, S., Avital, E., 1983. Foraging by queens of Cataglyphis bicolor nigra (Hymenoptera Formicidae): an unusual phenomenon among the formicinae. Israel J. Zool. 32: 229-230.

Grassé, P. P. 1942. Les rassemblements de sommeil des Hyménoptères et leur interprétation. Bull. Soc. Ent. Fr. 47: 142-148.

Grasse, P. P. 1984. Termitologia, 2: 65-144. Masson Paris.

Grasse, P. P., Noirot C. 1951. La sociotomie migration et fragmentation de la termitière chez les Anoplotermes et les Trinervitermes. Behaviour, 8: 146-166.

Haskins, C. P., Enzmann, E. V. 1955. On the occurrence of impaternates females in the formicidae. J. N.Y. Entomol. Soc., 53: 263-277.

HöllDOBLER, B. AND BARTZ, S. H. 1985. Sociobiology of reproduction in ants. In "Experimental Behavioral Ecology and Sociobiology", B. Hölldobler and M. Lindauer eds., Verlag, 237-257.

Hölldobler, B., Carlin, N. F.1985. Colony founding, queen dominance and oligogyny in the australian meat ant Iridomyrmex purpureus. Behav. Ecol. Sociobiol., 18: 45-58.

Hölldobler, B., Maschwitz, U. 1965. Der hochzeitsschwarm der Rossameise Camponotus herculeanus L. (Hym. Formicidae). Z. vergl. Physiol. 50: 551-568.

Hölldobler, B., Wilson, E. O. 1977. The number of queens: an important trait in ant evolution. Naturwissenschaften, 64: 8-15.

HölLDOBLER, B., Wilson, E. O. 1983. Queen control in colonies of weaver ants (Hymenoptera Formicidae). Ann. Entomol. Soc. Amer., 76: 235-238.

Howard, R. W., Mallette, E. J., Haverty, M. I., Smythe, R. V. 1981. Laboratory evaluation of within species, between species, and parthenogenetic reproduction in Reticulitermes flavipes and Reticulitermes virginicus. Psyche, 88: 75-87.

Itow, T., Kobayashi, K., Kubota, M., Ogata, K., Imai, H. I. and Crozier, R. H. 1984. The reproductive cycle of the queenless ant Pristomyrmex pungens. Insectes Soc., 31: 87-102.

Ledoux, A. 1950. Recherches sur la biologie de la fourmi fileuse (Oecophylla longinoda Latr.) Ann. Sc. Nat. Zool. lle sér.,12: 313-461. 
LEDOuX, A. 1952. Recherches préliminaires sur quelques points de la biologie d'Odontomachus assiniensis Latr. (Hyménoptères Formicidae). Ann. Sc. Nat. Zool., llème sér., 14: 231-248.

LeDoux, A. 1971. Un nouveau mode de bouturage de société chez la fourmi Aphaenogaster senilis Mayr. C. R. Acad. Sc. Paris, 273: D, 83-85.

Ledoux, A. 1973. A propos du bouturage de société chez la fourmi Aphaenogaster senilis Mayr. C.R. Acad. Sc. Paris 277: D, 2199-2200.

Ledoux, A. 1976. Bouturage expérimental de colonie chez la fourmi Aphaenogaster senilis Mayr. C. R. Acad. Sc. Paris, 283: D, 1061-1063.

Ledoux, A. 1984. Sur la présence d'ouvrières à parthénogenèse thélytoque observée chez Aphaenogaster senilis Mayr. (Hyménoptères Formicidae). C. R. Acad. Sc. Paris, sér. III, 299: 859-862.

Lenoir, A., Cagniant, H. 1986. Role of worker thelytoky in colonies of the ant Cataglyphis cursor (Hymenoptera: Formicidae). Entomol. Gener., 11: 153-157.

Lenoir, A., IsingrinI, M., NowbaharI, M. Colony recognition in the ant Cataglyphis cursor (Hymenoptera: Formicidae). In "Chemistry and Biology of Social Insects", J. Eder and H. Rembold, eds., Verlag J. Peperny, München. P. 476-477.

LEUTERT, W. 1963. Systematics of ants. Nature, 200: 496-497.

Lubin, Y. D., Robinson, M. H. 1982. Dispersal by swarming in a social spider. Science, 216: 319-321.

Mabelis, A. A. 1979. Nest splitting by the red wood ant (Formica polyctena Foerster). Neth. J. Zool., 29: 109-125.

Mizutani, H. 1980. Preliminary report on worker oviposition in the ant Pristomyrmex pungens Mayr. Kontyu, 48: 327-332.

MoRITZ, R. F. A. 1986. Two parthenogenetic strategies of laying workers in populations of the honeybee Apis mellifera (Hymenoptera Apidae). Entomol. Gener., 11: 159-164.

Nowbahari, M., Lenolr, A. 1984. La fermeture des sociétés de la fourmi Cataglyphis cursor: relation avec la distance géographique. In "Processus d'acquisition précoce. Les communications", A. de Haro and X. Espadaler eds., Public. Univ. Autonoma. Barcelone et Soc. Fr. Et. Comp. Anim., 457-461.

ONo, S. 1983. A preliminary note on the thelytokous parthenogenesis of Pristomyrmex pungens Mayr. Ari Rep. Myrmecol. Soc., 11: 4 (in japanese).

Oтто, D. 1960. Zur Erscheinung der Arbeiterinnenfertilität und parthenogenesa bei Kahlrückigen Roten Waldameisen (Formica polyctena Först). Deut. Entomol. Z., 7: 1-9.

Pamilo, P., Crozier, R. H., Frazer, J: 1985. Internest interactions, nest autonomy and reproductive specialization in an australian arid-zone ant Rhytidoponera sp. 12. Psyche, 12: 217-236.

Peeters, C., Creewe, R. 1984. Insemination controls the reproductive division of labour in a Ponerine Ant. Naturwissenschaften, 71: 50.

Porter, S. D., TSChINkel, W. R. 1986. Adaptative value of nanitic workers in newly founded red imported fire ant colonies (Hymenoptera Formicidae). Ann. Entomol. Soc. Amer., 79: 723-726.

Raignier, A., van Boven, J. 1955. Etude taxonomique, biologique et biométrique des Dorylus du sous-genre Anomma (Hymenoptera Formicidae). Ann. Mus. Roy. Congo Belge, N.S., Sc. Nat., 2: 1-359. 
RetanA, J. 1986. Estudio de la division del trabajo y de la variabilidad individual en las colonias de Cataglyphis cursor (Hym. Formicidae). Ph. Thesis, Univ. Barcelona.

Rettenmeyer, C. W. 1963. Behavioural studies of army ants. Univ. Kansas Sci. Publ., 44: 281-465.

Roisin, Y., Pasteels, J. and Braekman, J. C. 1989. Soldier diterpene patterns in relation with aggressive behaviour. Spatial distribution and reproductive status of colonies in Nasutitermes princeps. Biochem. Syst. Ecol., 15: 253-261.

Roisin, Y., Pasteels, J. 1986a. Reproductive mechanisms in Termites: polycalism and polygyny in Nasutitermes polygynes and $N$. costalis. Insectes Soc., 33: 149-167.

Roisin, Y., Pasteels, J. 1986b. Replacement of reproductives in Nasutitermes princeps (Desneux) (Isoptera: Termitidae). Behav. Ecol. Sociobiol., 18: 437-442.

Rosengren, R., Cherix, D. and Pamilo, P. 1986. Insular ecology of the red wood ant Formica truncorum Fabr. II. Distribution, reproductive strategy and competition. Mitt. Schw. Entomol. Gesel., 59: 63-94.

Rosengren, R. And Pamilo, P. 1983. The evolution of polygyny and polydomy in mound-building Formica ants. Acta Entomol. Fennica, 42: 65-77.

Santschi, F. 1929. Etudes sur les Cataglyphis. Rev. Suisse Zool., 36: 25-70.

SCHMid-Hempel, P. 1987. Foraging characteristics of the desert ant Cataglyphis. In "From individual to collective behavior in social insects", J. M. Pasteels and J. L. Deneubourg eds, Experientia suppl. 54: 43-61.

Schneirla, T. C. AND Brown, R. Z. 1950. Army ant life and behavior under dry season conditions. 4. Further investigation of cyclic proceses in behavioral and reproductive functions. Bull. Amer. Mus. Nat. Hist., 95: 263-353.

Shalmon, B. 1982. A comparative ethological study of five species of ants from the genus Cataglyphis (Formicidae) in Eilat. Unpublished Ph.D., Hebrew Univ. Jerusalem.

Soulie, J. 1960. Des considérations écologiques peuvent-elles apporter une contribution à la connaissance du cycle biologique des colonies de Crematogaster. Insectes Soc., 7: 283-295.

Spradbery, J. P. 1973. Wasps. Sidgwick and Jackson, London.

StUART, R. L. 1985. Spontaneous polydomy in laboratory colonies of the ant Leptothorax curvispinosus Mayr (Hymenoptera Formicidae). Psyche, 92: 71-81.

SuDD, J. H. 1967. An introduction to the behaviour of ants. Arnold. London.

Suzzoni, J. P., Cagniant, H. 1975. Etude histologique des voies génitales chez l'ouvrière et la reine de Cataglyphis cursor Fonsc. (Hyménoptères, Formicidae, Formicinae). Arguments en faveur d'une parthénogénèse thélytoque chez cette espèce. Insectes Soc., 22: 83-92.

ThORNe, B. L. 1982. Polygyny in Termites: multiple primary queens in colonies of Nasutitermes corniger (Motschuls) (Isoptera: Termitidae). Insectes Soc., 29: 102-117.

ThorNe, B. L. 1984. Polygyny in the neotropical termite Nasutitermes corniger. Life history consequences of queen mutualism. Behav. Ecol. Sociobiol., 14: 117-136.

Traniello, J. F. A. 1982. Population structure and social organization in the primitive ant Amblyopone pallipes (Hymenoptera Formicidae). Psyche, 65: 65-80. 
Tshinkel, W. R., Howard R. W. 1978. Queen replacement in orphaned colonies of the fire ant Solenopsis invicta. Behav. Ecol. Sociobiol., 3: 297-310.

WAY, M. J. 1954. Studies of the life-history and ecology of the ant Oecophylla longinoda Latr. Bull. Entomol. Res., 45: 93-112.

Wehner, R., Harkness, R. D., Schmid-Hempel, P. 1983. Foraging strategies in individually searching ants Cataglyphis bicolor (Hymenoptera Formicidae). In "Information Processing in Animals," 1: 79 p., Verlag.

Wesson, L. G. 1939. Contribution to the natural history of Harpagoxenus americanus (Hymenoptera, Formicidae). Trans. Am. Entomol. Soc., 65: 97-122.

WheEler, W. M. 1910. Ants. Columbia University Press.

Wilson, E. O. 1971. The Insect Societies. Belknap Press Harvard, Cambridge.

Yamauchi, K., Kinomura, K., Miyake, S. 1981. Sociobiological studies of the polygynic ant Lasius sakagamii. I. General features of its polydomous system. Insectes Soc., 28: 279-296. 

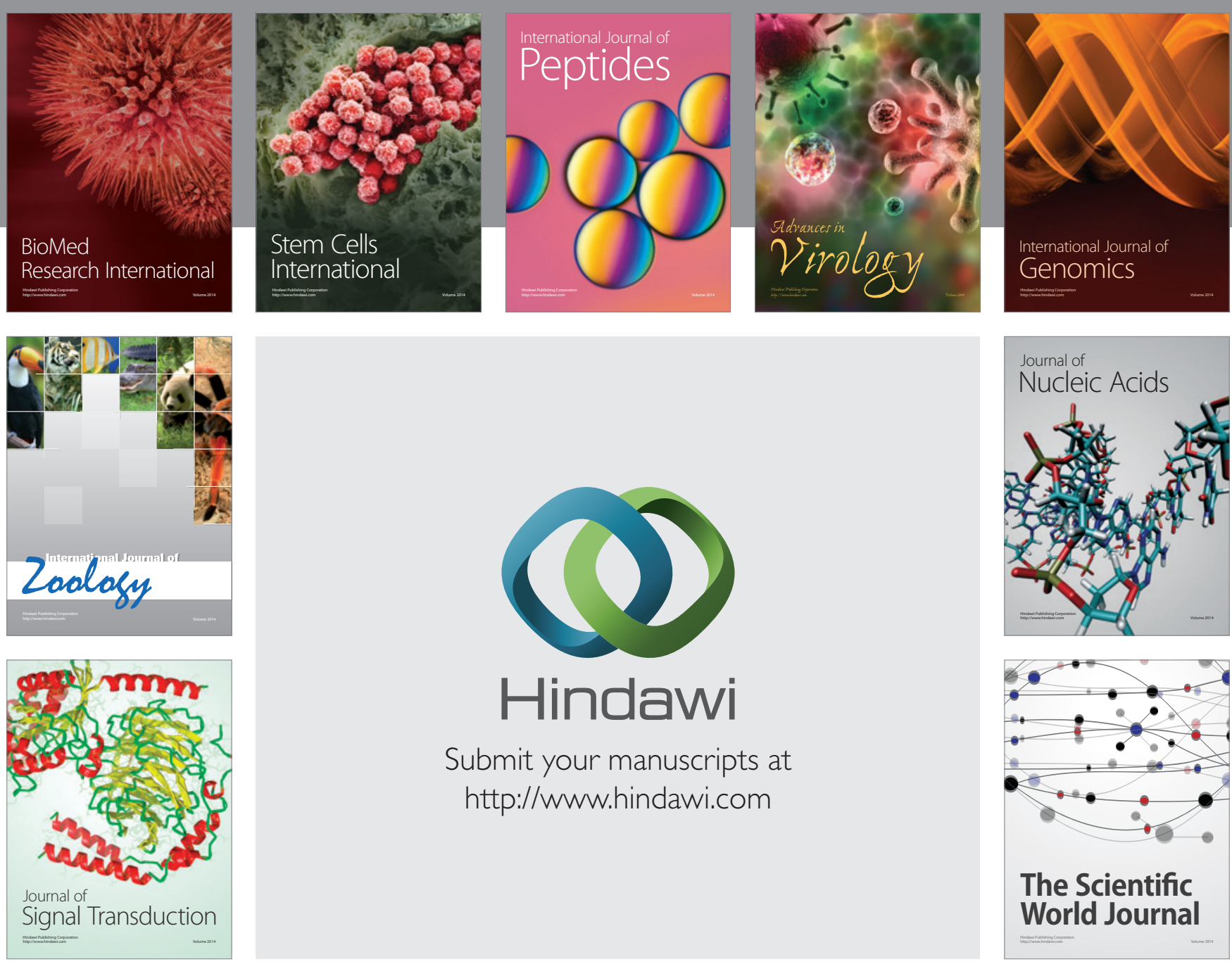

Submit your manuscripts at

http://www.hindawi.com
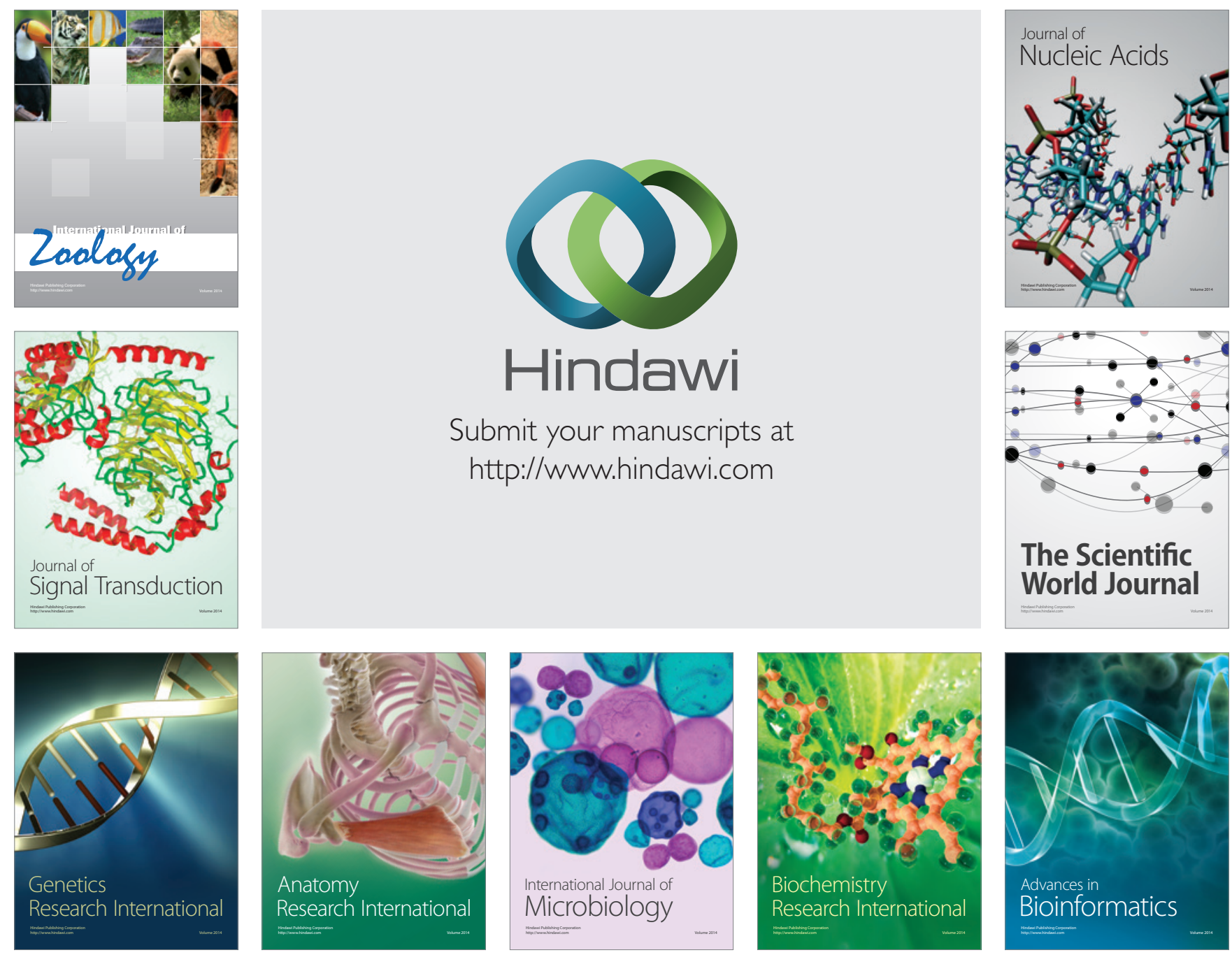

The Scientific World Journal
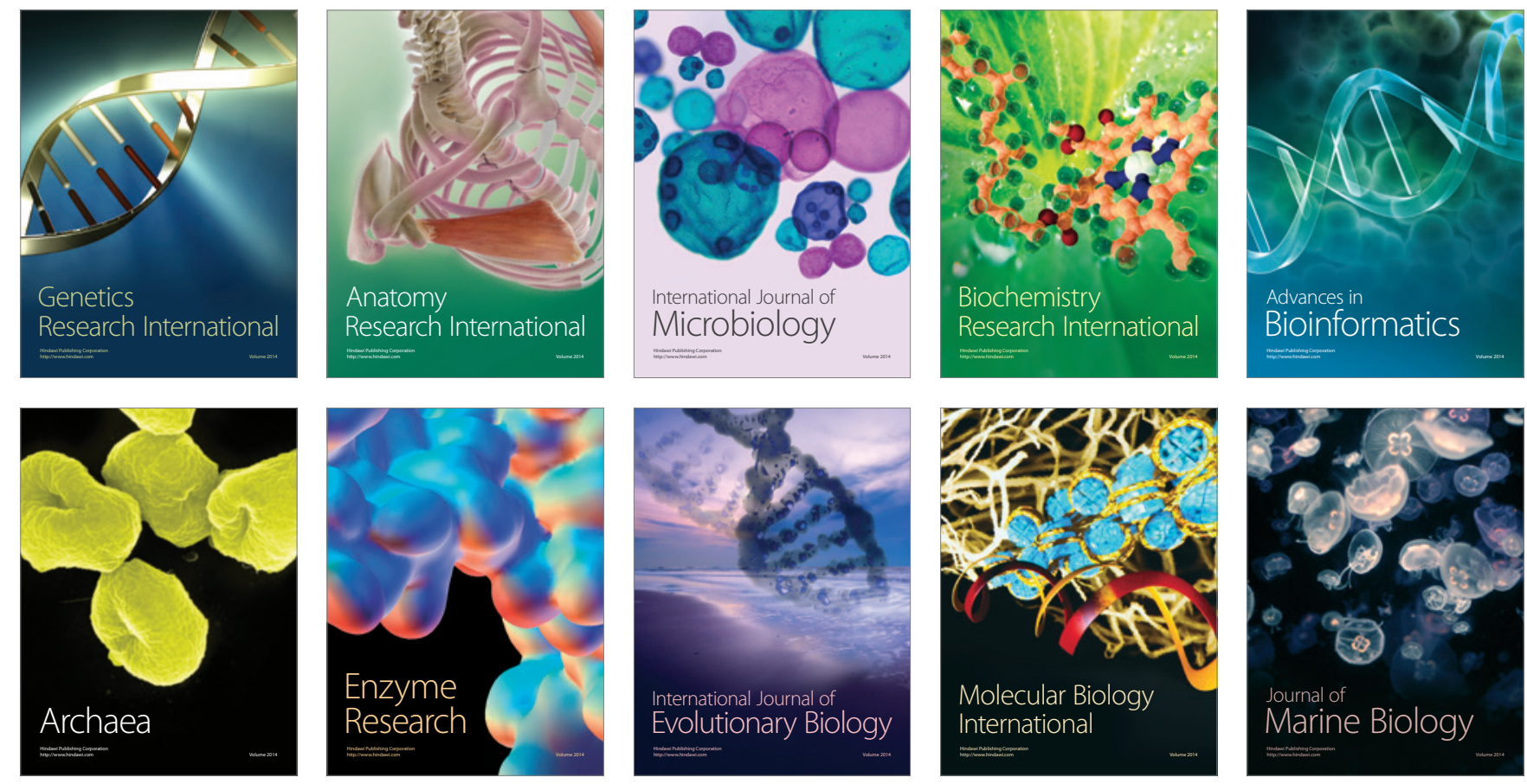